\section{A Naturally Occurring Compound for Controlling Powdery Mildew of Greenhouse Roses}

\author{
Steven E. Newman ${ }^{1}$ and Michael J. Roll ${ }^{2}$ \\ Department of Horticulture and Landscape Architecture, Colorado State \\ University, Fort Collins, CO 80523-1173
}

\author{
Ronald J. Harkrader ${ }^{3}$ \\ Camas Technologies, Inc., P.O. Box 1357, Broomfield, CO 80038-1357
}

Additional index words. biorational pesticides, Rosa, Sphaerotheca pannosa

\begin{abstract}
Quaternary benzophenanthridine alkaloids (QBAs) isolated from plants in the family Papaveraceae are effective for the control of some fungal diseases. Extracts from Macleaya cordata, a species rich in QBAs, were formulated at $150 \mathrm{mg} \cdot \mathrm{L}^{-1} \mathrm{QBA}$ for spray application to greenhouse roses (Rosa sp.) infected with Sphaerotheca pannosa var. rosae (powdery mildew). The QBA formulation was applied at 10-day intervals. For comparison, copper sulfate pentahydrate, piperalin, and fenarimol also were applied to mildewinfected plants within the same greenhouse at their respective labeled rates. One day after treatment, visible symptoms of mildew infection were reduced $60 \%$ by QBA, whereas fenarimol, copper sulfate pentahydrate, and piperalin reduced the symptoms of infection $50 \%, 75 \%$, and $85 \%$, respectively. Subsequent studies demonstrated that a tank mix of QBA and piperalin provided enhanced control of powdery mildew on rose. Results from this study indicate that QBAs have the potential to be developed as a biorational fungicide for greenhouse use with both fungicidal and fungistatic activity.
\end{abstract}

Quaternary benzophenanthridine alkaloids (QBAs) are effective in the control of some fungal diseases of garden and ornamental crops (Howell et al., 1973). The QBAs belong to a large group of isoquinoline alkaloids biosynthesized from phenylalanine(Harkrader et al., 1990). They are widely distributed in nature and can be found in plants of the families Papaveraceae, Fumariaceae, and Rutaceae. Biological activities and pharmacological properties of the benzophenanthridine alkaloids have been elucidated and their biological safety range, as well as their interactions with biological systems, have been determined. These activities include antimicrobial (Godowski, 1989), antifungal (Vichkanova and Adgina, 1971), anti-inflammatory (Lenfield et al., 1981), antiprotozoal (Vichkanova et al., 1969), and sodium/potassium ATPase effects (Pitts and Meyerson, 1981). They inhibit the activity of protein kinase C (Herbert et al., 1991), acetylcholinesterase (Ultrichova et al., 1983b), butyryl cholinesterase (Ultrichova et al., 1983a), alanine aminotransferase (Walternova et al., 1981), and collagenase and bone resorption (Sakamoto, 1986), as well as photophos-

Received for publication 21 May 1998. Accepted for publication 16 Oct. 1998. Funding was provided by Camas Technologies, Inc., Interregional Research Project No. 4 (IR-4) Biopesticide Research Program, and Colorado Agricultural Experiment Station (project 642). The cost of publishing this paper was defrayed in part by the payment of page charges. Under postal regulations, this paper therefore must be hereby marked advertisement solely to indicate this fact.

${ }^{1}$ Associate Professor.

${ }^{2}$ Research Associate.

${ }^{3}$ President. phorylation (Vallejos, 1973) and respiration (Vallejos and Roveri, 1972). These compounds also act as nematicides (Onda et al., 1965), macrophage cell activators, and positive inotropic agents on cardiac muscle (Agarwal et al., 1991).

The major QBAs are sanguinarine and chelerythrine. The richest natural sources of these two alkaloids are the plants Sanguinaria canadensis L., Dicranostigma lacucoides Hook.f. \& T. Thoms., and Chelidonium majus L., which are found throughout the world (Harkrader et al., 1991). Sanguinaria canadensis (sanguinaria) is a perennial herb occurring widely in the eastern parts of North America (Bailey and Bailey, 1976). Common names in American literature for this plant include red root, blood root, puccoon root, and tetterwort (Martin, 1984). Sanguinaria was one of the first species to be investigated for its alkaloid content because of its conspicuous appearance and folkloric accounts of its use as a natural medicine. Macleaya cordata (Willd.) $\mathrm{R}$. Br. is a perennial plant native to temperate regions of China and Japan (Bailey and Bailey, 1976). The benzophenanthridine alkaloid content of Macleaya cordata is $0.5 \%$ to $2 \%$ (Harkrader et al., 1991).

Sanguinarine is fungistatic on several plant fungal pathogens, including Phytomatotrichum omnivorum (Duggar) Hennebert, Sclerotium rolfisii Sacc., Gaeumannomyces graminis (Sacc.) Arx and D. Oliver (Ophiobolus graminis), Rhizoctonia solani Kühn, Amillaria mellea (Vahl: Fr.) Kummer, Fusarium oxysporum Schlecht. (F. vasinfectum), and Verticillium albo-atrum Reinke and Berthier (Greathouse, 1939; Greathouse and Rigler, 1940; Howell et al., 1973; Presley, 1969). All of these aforementioned studies were conducted in vitro. No reports of the application of QBAs directly to plants for the control of fungal pathogens have been found in the literature.

Laboratory studies with rats fed a diet for $14 \mathrm{~d}$ with up to $150 \mathrm{mg} \cdot \mathrm{L}^{-1}$ sanguinarine, a benzophenanthridine alkaloid, showed no toxic effects (Becci et al., 1987). Evaluations of reproductive and developmental toxicology showed that orally administered sanguinarine had no adverse effects on estrous cycling, male or female copulatory and fertility indices, or gestation/lactation parameters of rats fed $10-100 \mathrm{mg} \cdot \mathrm{kg}^{-1}$ per day (Keller and Meyer, 1989). Human clinical studies using commercial dentifrice samples $(0.2 \%$ sanguinarine formulation) repeatedly applied to oral mucosal tissues showed no treatment-related lesions (Frankos et al., 1990). The fungistatic sanguinarine concentrations ranged from 2.5 to $320 \mu \mathrm{g} \cdot \mathrm{mL}^{-1}$ in these tests.

The objective of the study reported here was to compare a fungicide formulated with QBAs extracted from Macleaya cordata with commercial fungicides for control of powdery mildew infecting greenhouse roses.

\section{Materials and Methods}

Hybrid rose plants, cultivars Gabriella, Royalty, Samantha, and Sonia, were established in granulated rockwool (Par-gro medium grade rockwool), in a single layer, fiberglass-reinforced plastic greenhouse. Plants were placed one per $0.093 \mathrm{~m}^{2}$ in groups of 30 per block with each of two $1.07 \times 10.7-\mathrm{m}$ benches containing all four cultivars. Groups of cultivars were randomized on each bench. Plants were irrigated daily with a liquid nutrient solution containing $\left(\mathrm{mg} \cdot \mathrm{L}^{-1}\right) 200 \mathrm{~N}, 13 \mathrm{P}$, $264 \mathrm{~K}$, and $16 \mathrm{Mg}$. Micronutrients were supplied by a soluble trace element mix (STEM; The Scotts Co., Marysville, Ohio) at $0.96 \mathrm{~S}$, $0.22 \mathrm{Cu}, 0.51 \mathrm{Fe}, 0.55 \mathrm{Mn}, 0.0027 \mathrm{Mo}, 0.31$ $\mathrm{Zn}$, and $0.093 \mathrm{~B} \mathrm{mg} \cdot \mathrm{L}^{-1}$. Iron was supplied by Sequestrene 330 at $0.20 \mathrm{mg} \cdot \mathrm{L}^{-1}$.

Greenhouse conditions conducive to powdery mildew development were maintained during Fall 1995 and Winter 1996 for preliminary studies. The temperature was maintained at $22 \pm 2{ }^{\circ} \mathrm{C}$ day and $19 \pm 2{ }^{\circ} \mathrm{C}$ night. At the end of each day, the gravel floors were sprayed with water to increase the humidity in the greenhouses, encouraging Sphaerotheca pannosa (Wallr.: Fr.) Lêv var. rosae Woronichin (powdery mildew) infection.

Expt. 1. After powdery mildew infection was established at a minimum of $20 \%$ of the total leaf area, three concentrations of a Macleaya cordata QBA fungicide formulation, 75,150 , or $300 \mathrm{mg} \cdot \mathrm{L}^{-1}$ (Camas Technologies, Broomfield, Colo.) and a control (water) treatment were applied onto leaflet surfaces to the point of drip in the greenhouse. The control was a plain water spray, which is a treatment often used by rose growers as an effective mildew control strategy for slight infections. The four treatments were randomly applied to two blocks of each cultivar. The degree of mycelial development was rated 4, 7, and $11 \mathrm{~d}$ 
after application. Mildew infection was rated visually as a percentage of total coverage on morphologically similar, five-leaflet leaves tagged on four stems of each cultivar in each block. The percentage of reduction of mycelium coverage relative to the initial leaflet coverage was determined.

Expt. 2. After the first experiment was terminated, the mildew infection was allowed to proceed at a level equal to or greater than $35 \%$ of the total leaf area. The QBA fungicide formulation was applied at $150 \mathrm{mg} \cdot \mathrm{L}^{-1}$ to one block of the rose plants as previously described. To the other four blocks of rose plants, copper sulfate pentahydrate (Phyton-27 5.5EC; Source Technology Biologicals, Minneapolis), piperalin (Pipron 82.4EC; SePro Corp., Carmel, Ind.), fenarimol (Rubigan 12.5EC; DowElanco, Indianapolis, Ind.), and a water control were applied to mildew-infected plants at their respective label rates. With piperalin, $1.3 \mathrm{~mL} \cdot \mathrm{L}^{-1}$ potassium salts of fatty acids (insecticidal soap, M-Pede; Mycogen Corp., San Diego) was added as a surfactant. All products were applied at 10-d intervals. Mildew infection was rated visually as previously described, and the percentage of mycelium coverage compared with the water control.

Expts. 3 and 4. The next two studies were conducted during Dec. 1996 and Jan. 1997 using the original rose plants. As previously described, the greenhouse environment was conducive to powdery mildew development, which was allowed to establish at a level equal to or $>35 \%$ for each study. For each study, the QBA fungicide formulation was applied at 75 $\mathrm{mg} \cdot \mathrm{L}^{-1}$, one-half the previous rate. This rate was selected after noting that the effect of this treatment was similar to that obtained at higher rates $10 \mathrm{~d}$ after application. Copper sulfate pentahydrate, piperalin, and fenarimol were applied to mildew-infected plants at their respective label rates for comparison as previously described; water sprays were again used as the control. An additional treatment was included, which was a "tank mix" of piperalin at its labeled rate, combined with QBA at 75 $\mathrm{mg} \cdot \mathrm{L}^{-1}$. No surfactant was included in this tank mix because the surfactant levels in the QBA formulation were adequate for piperalin performance. During the December study, a second application was applied after $6 \mathrm{~d}$ and a third $18 \mathrm{~d}$ later. During the January study, the second application was applied after $7 \mathrm{~d}$ and the third $10 \mathrm{~d}$ later. Mildew infection was rated visually as previously described. Infection data were analyzed as the percentage of reduction of mycelium coverage based on the initial leaflet coverage.

Expt. 5. A final trial to demonstrate the efficacy of QBA control of powdery mildew on greenhouse roses was conducted during September 1997 at two commercial cut-rose greenhouses. Franktown Floral (Franktown, Colo.) and Pikes Peak Greenhouses (Colorado Springs, Colo.) were chosen as the evaluation sites; each greenhouse had a resident infection of powdery mildew. At Franktown Floral, four QBA treatments were applied to 'Royalty' roses; these were an untreated control, a plain water spray, and QBA formulation rates of 25 and $50 \mathrm{mg} \cdot \mathrm{L}^{-1}$. At Pikes Peak Greenhouse, six treatments were applied to 'Gabriella' roses, including two controls as previously described, and five QBA formulation rates $\left(12.5,25,38,50\right.$, and $\left.75 \mathrm{mg} \cdot \mathrm{L}^{-1}\right)$. Lower rates were evaluated to determine a minimum level of efficacy of the QBA. Mildew infection was rated visually as previously described, but using five stems. Infection data were analyzed as the percentage of reduction of mycelium coverage compared with the initial leaflet coverage $8 \mathrm{~d}$ after product application.

\section{Results and Discussion}

Under our greenhouse conditions, the hybrid rose cultivars Gabriella, Royalty, Samantha, and Sonia all were equally susceptible to powdery mildew infection. In each subsequent study, no differences due to cultivar were detected; therefore, data for all cultivars were pooled.

Expt. 1. In the 1995-96 study, all rates of the QBA fungicide formulation had significantly reduced mildew infection after $15 \mathrm{~d}$ (Fig. 1). The $150-\mathrm{mg} \cdot \mathrm{L}^{-1}$ QBA was the rate selected for the next study.

Expt. 2. Three days after treatment, the effect of the QBA fungicide formulation was similar to that of commercial fungicides fenarimol, copper sulfate pentahydrate, and piperalin in controlling powdery mildew (Fig. 2). The same was true after $7 \mathrm{~d}$ (data not shown). Piperalin and copper sulfate pentahydrate are both fungal eradicants and eliminate mildews quickly, but have little residual activity, thus requiring applications every 5 to $10 \mathrm{~d}$ (Powell, 1998). Fenarimol, a demethylation-inhibiting fungicide (van den Brink et al., 1996), serves as a protectant/ eradicant for control of powdery mildews, and has long-term residual activity (Powell, 1998). Piperalin is a potent inhibitor of growth and ergosterol biosynthesis in sporidia of Ustilago maydis (DC.) Cda. (Schneegurt and Henry, 1992). Rose growers often rotate piperalin with fenarimol for residual, as well as protectant, disease management (Powell, 1998).

The broad-spectrum antimicrobial activity of QBAs appears to involve the inhibition of specific enzymes. Sanguinarine and chelerythrine break down the inner electron-dense layer of the cell walls of Pseudomonas aeruginosa (Schroeter) Migula and deform partitions between daughter cells. At higher QBA levels, bacterial cell walls also become thinner, and cell aggregation occurs (Beekov et al., 1983). Many other enzyme activities may be competitively or noncompetitively inhibited by QBAs, depending on the enzyme in question (Godowski, 1989). Whether the antifungal activity demonstrated in this study reflects inhibition of a specific enzyme activity was not determined.

Expts. 3 and 4. Many growers routinely tank-mix piperalin with thiophanate-methyl

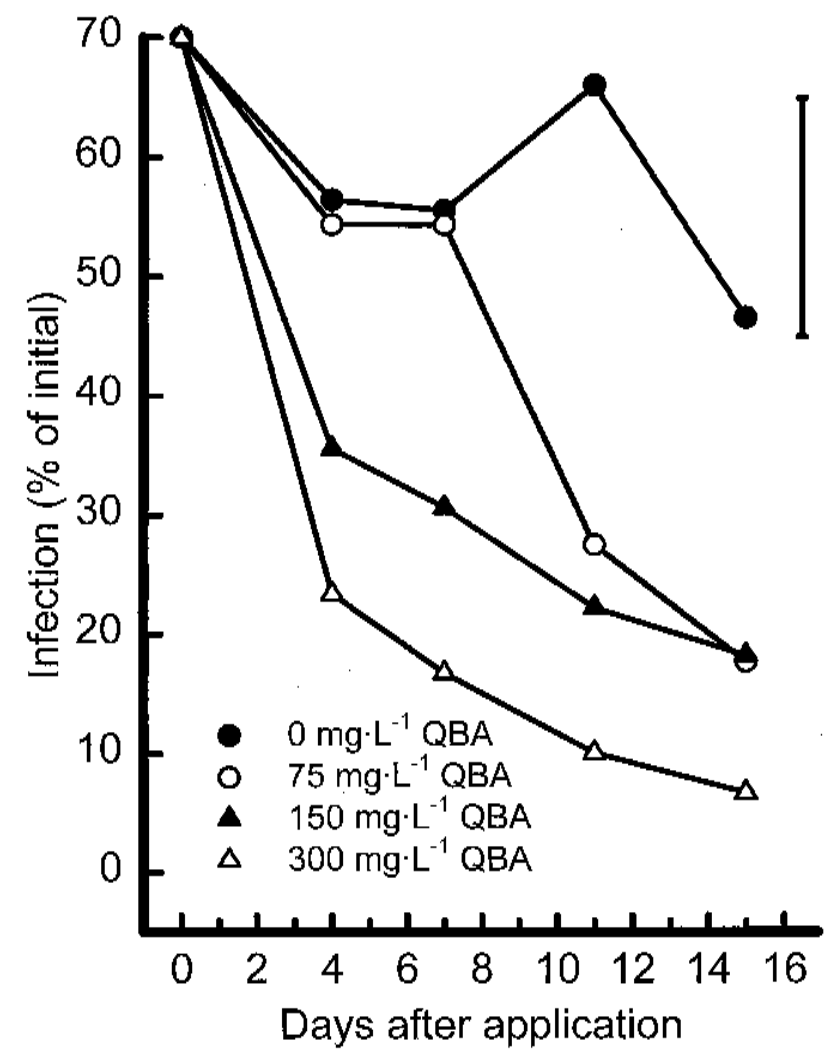

Fig. 1. Effect of concentration of quaternary benzophenanthridine alkaloids (QBAs) on percentage of reduction of Sphaerotheca pannosa var. rosae (powdery mildew) infecting greenhouse roses. Each mean represents 32 observations from the four cultivars ('Gabriella', 'Royalty', 'Samantha', and 'Sonia') pooled. Vertical bars represent least significant differences at $P \leq 0.05$. 


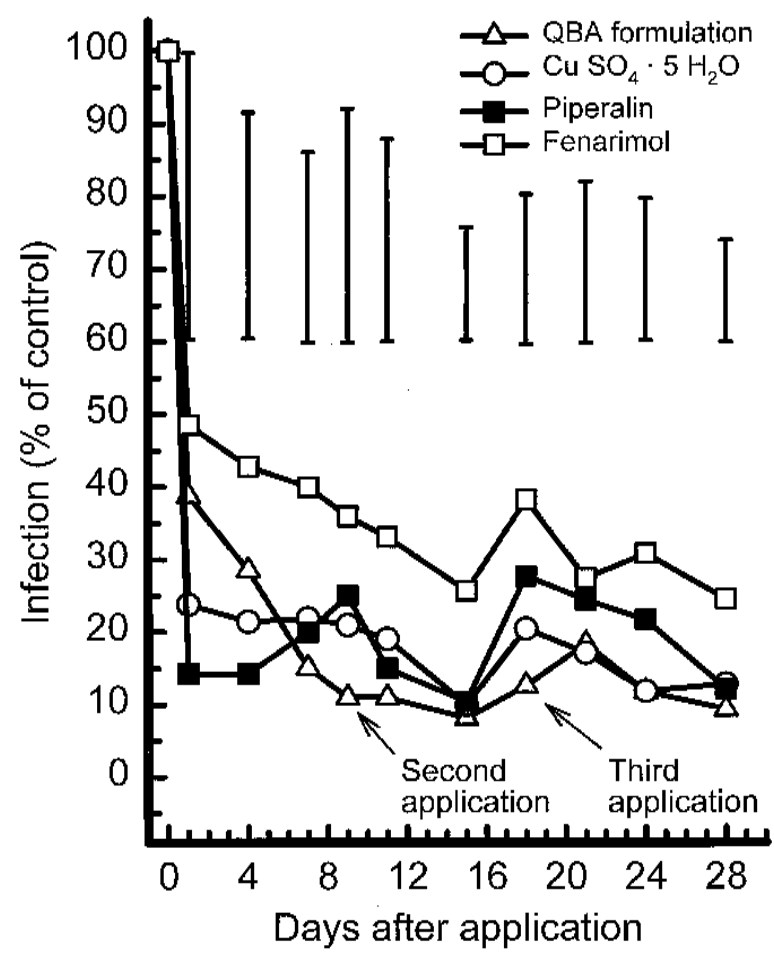

Fig. 2. Effect of quaternary benzylphananthridine alkaloids (QBAs), $\mathrm{CuSO}_{4} \cdot 5 \mathrm{SO}_{4}$, piperalin, fenarimol, and a water control applied at 10-d intervals on percentage of reduction of Sphaerotheca pannosa var. rosae (powdery mildew) infecting greenhouse roses. Each mean represents 32 observations from the four cultivars ('Gabriella', 'Royalty', 'Samantha', and 'Sonia') pooled. Vertical bars represent least significant differences at $P \leq 0.05$

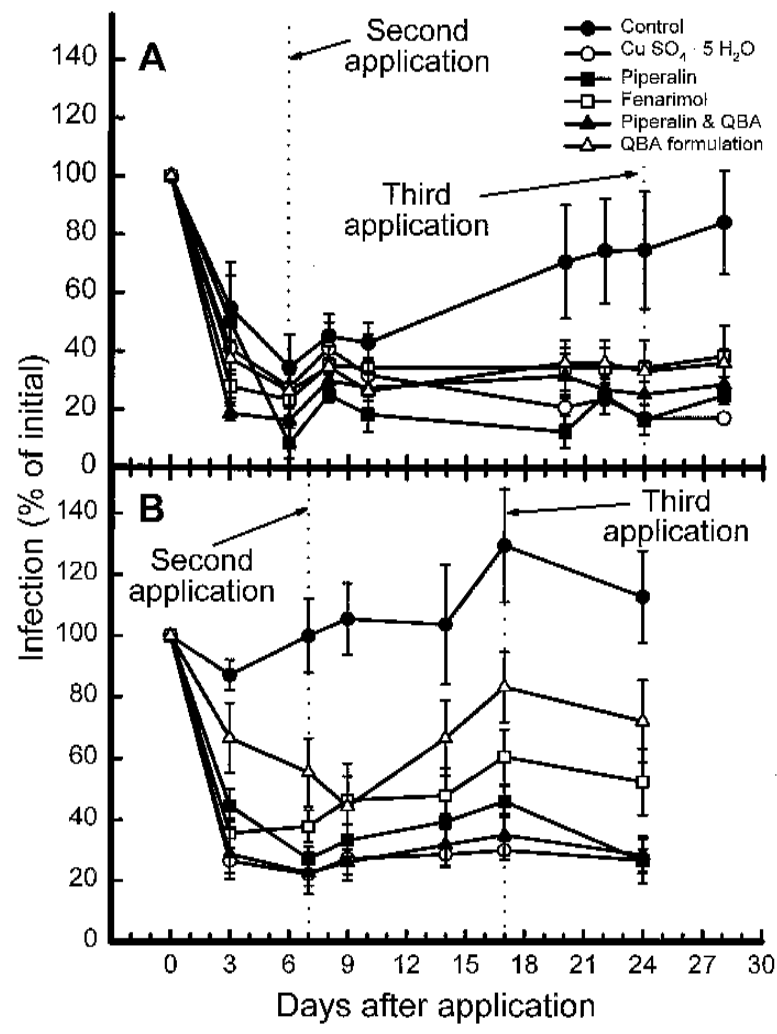

Fig. 3. Effects of application of quaternary benzylphananthridine alkaloids (QBAs), $\mathrm{CuSO}_{4} \cdot 5 \mathrm{SO}_{4}$, piperalin, fenarimol, piperalin and QBAs tank mix, and a water control, with subsequent applications at (A) 6 and 24 d after treatment during Dec. 1996 or (B) 7 and 17 d during Jan. 1997, on percentage of reduction of Sphaerotheca pannosa var. rosae (powdery mildew) infection on greenhouse roses. Each mean represents 32 observations from the four cultivars ('Gabriella', 'Royalty', 'Samantha', and 'Sonia') pooled. Vertical bars represent least significant differences at $P \leq 0.05$.

for eradicant and long-term control of powdery mildew (Powell, 1998). Considering this, and the fact that the QBA formulation was not as immediately effective in eradicating powdery mildew as piperalin, but had a longer efficacy, a series of "tank mix" trials were conducted. During the 1996-97 studies, initially, 3 to $6 \mathrm{~d}$ after application, all singlefungicide formulations performed as in the earlier trial (Fig. 3A). During the Dec. 1996 trial, the QBA/piperalin tank mix was more effective than the single formulations, but after the second and third applications, the tank mix was no more effective than was copper sulfate pentahydrate or piperalin; however, it was more effective than QBA or fenarimol alone (Fig. 3A). During the Jan. 1997 trial, the QBA/piperalin tank mix controlled powdery mildew more effectively than did QBA alone, and was as effective as piperalin, fenarimol, or copper sulfate pentahydrate 3 or $6 \mathrm{~d}$ after application (Fig. 3B). Two weeks after the initial application the QBA/piperalin tank mix remained as effective as copper sulfate pentahydrate, and these treatments were more effective than the other fungicides until after a third application (Fig. 3B).

The enhanced control of powdery mildew by the QBA/piperalin tank mix can probably be attributed to piperalin as an eradicant, which gives good immediate mildew control, and QBA as a more slowly effective fungicide, which extends mildew control over a longer period. This combination may allow a rose grower to reduce the frequency of pesticide applications. No tank mixes of copper sulfate pentahydrate with QBA were evaluated because the former has a 24-h restricted interval for worker reentry (Powell, 1998), which makes it an undesirable pesticide in a rose greenhouse. Piperalin and fenarimol have a 12-h restricted interval and are both commonly used by rose growers. The QBA product used in this experiment, as currently formulated, should qualify for a 12-h, and possibly 4-h, restricted entry interval, which will make it an attractive new product for rose growers.

Expt. 5. To this point, all of the QBA trials were conducted at Colorado State Univ. For final verification of efficacy, trials were conducted at two commercial rose greenhouses using a series of QBA rates. Even though the greenhouses differed in glazing, environment, location, and cultivars, the results were similar at both; thus, the data were pooled for statistical analysis. Eight days after application, even the lowest rate $\left(12.5 \mathrm{mg} \cdot \mathrm{L}^{-1}\right)$ was effective in controlling powdery mildew (Fig. 4); however, the 38 and $50 \mathrm{mg} \cdot \mathrm{L}^{-1}$ rates yielded the most consistent control. The rose grower's observations at each location provided additional confirmation of the relative degree of control.

The QBA formulation was effective in eradicating and controlling Sphaerotheca pannosa var. rosae. Quaternary benzophenanthridine alkaloids extracted from Macleaya cordata have the potential to provide the active ingredient for an effective biorational pesticide for the greenhouse rose industry, equal to or better than some of the fungicides currently used.

HortScience, Vol. 34(4), July 1999 


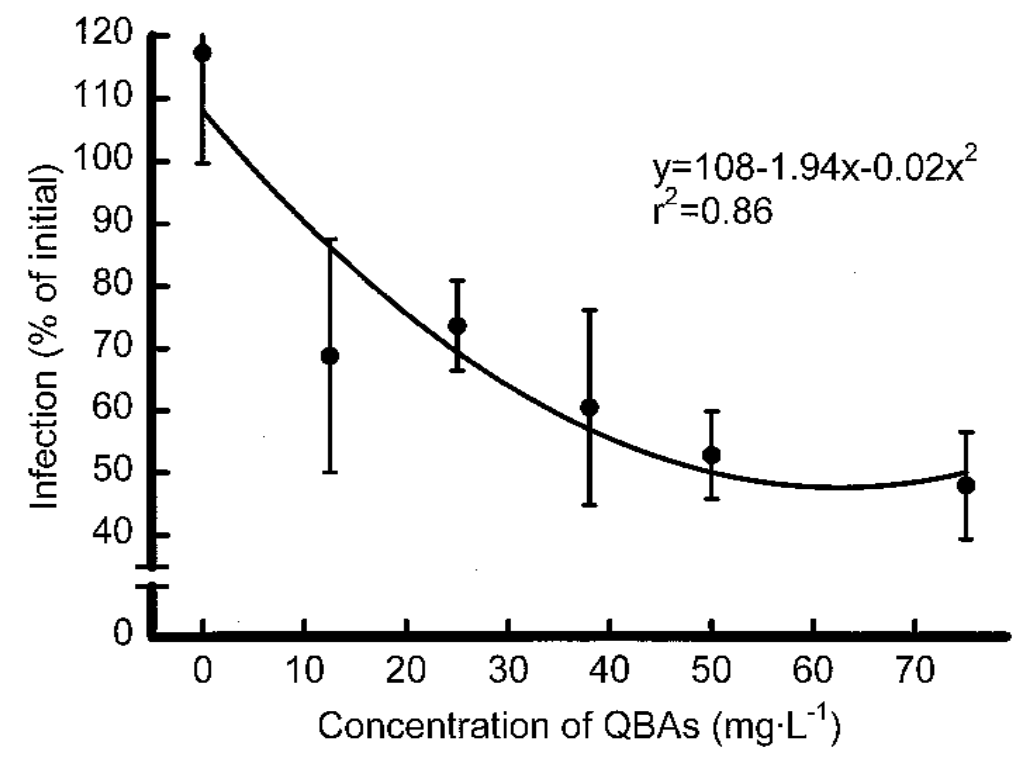

Fig. 4. Efficacy of quaternary benzylphananthridine alkaloids (QBAs) $8 \mathrm{~d}$ after application to greenhouse roses (cultivars Gabriella and Royalty) for control of Sphaerotheca pannosa var. rosae (powdery mildew) infection in commercial greenhouses during Sept. 1997. Each point is the mean of total of 16 observations from the two cultivars and sites pooled. Vertical bars represent least significant differences at $P \leq 0.05$.

\section{Literature Cited}

Agarwal, S., M.A. Reynolds, S. Pou, D.E. Peterson, J.A. Charon, and J.B. Suzuki. 1991. The effect of sanguinarine on human peripheral blood neutrophil viability functions. Oral Microbiol. Immunol. 6:51-61.

Bailey, L.H. and E.Z. Bailey. 1976. Hortus third: A concise dictionary of plants cultivated in the United States and Canada. Macmillan, New York.

Becci, P.J., H. Schwartz, H.H. Barnes, and G.L. Lee. 1987. Short-term toxicity studies of sanguinarine and two alkaloid extracts of Sanguinaria canadensis L. J. Tox. Environ. Health 20:199_ 208.

Beekov, A.C., C.A. Vichkanova, A.C. Sleznev, R.V.Fateeva, E.P.Pashkov, and I.M. Sechenova. 1983. Electron microscope studies of the effects of sanguinarine on microorganisms: Experiments in vitro (in Russian). Antibiotika 28:421-424.

Frankos, V.H., D.J. Brusick, E.M. Johnson, H.I. Maibach, I. Munro, R.A. Squire, and C.S. Weil. 1990. Safety of sanguinaria extract as used in commercial toothpaste and oral rinse products. J. Can. Dent. Assn. 56:41-47.

Godowski, K.C. 1989. Antimicrobial action of sanguinarine. J. Clin. Dent. 1:96-101.

Greathouse, G.A. 1939. Alkaloids from Sanguinaria canadensis and their influence on growth of Phymatotrichum omnivorum. Plant Physiol. 14:377-380.
Greathouse, G.A. and N.E. Rigler. 1940. The chemistry of resistance to Phymatotrichum root rot. $\mathrm{V}$. Influence of alkaloids on growth of fungi. Phytopathology 57:1264-1267.

Harkrader, R.J., P.C. Reinhart, J.A. Rogers, R.R. Jones, R.E. Wylie II, B.K. Lowe, and R.M. McEvoy. 1990. The history, chemistry, and pharmacokinetics of sanguinaria extract. J. Can. Den. Assn. 56:7-12 (suppl.).

Harkrader, R.J., P.C. Reinhart, R.E. Wylie II, B.K. Lowe, R.L. Dunn, and G.L. Southard. 1991. Purity of sanguinarine isolated from Sanguinaria canadensis $\mathrm{L}$. and Macleaya spp. for the treatment of periodontal disease. In: J. Fleurentin (ed.). Ethnopharmacology: Sources, methods, objectives (in French and English). First European Symp. on Ethnopharmacology, 23-25 Mar. 1990, Metz, France. (Abstr.)

Herbert, J.M., J.M. Augereau, J. Gleye, and J.P. Maffrand. 1991. Chelerythrine is a potent inhibitor and specific inhibitor of protein kinase $\mathrm{C}$. Biochem. Biophys. Res. Commun. 172:939999.

Howell, C.R., A.A. Bell, and R.D. Stipanovic. 1973. Virulence to cotton and tolerance to sanguinarine among Verticillium species. Can. J. Microbiol. 19:1367-1371.

Keller, K.A. and D.L. Meyer. 1989. Reproductive and developmental toxicological evaluation of sanguinaria extract. J. Clin. Dent. 1:59-66.

Lenfield, J., M. Karoutil, E. Marsalek, J. Slavik, V. Preininger, and V. Simanek. 1981. Antiinflam- matory activity of quaternary benzophenanthridine alkaloids from Chelidonium majus. J. Med. Planta Med. 43:161-165.

Martin,L.C. 1984. Wildflower folklore. East Woods Press, Charlotte, N.C.

Onda, M., K. Takiguchi, M. Hirakura, H. Fukushima, M. Akagawa, and F. Naoi. 1965. The constituents of Macleaya cordata. I. Nematicidal alkaloids (in Japanese). Nippon Nogei Kagaku Kaishi 39:168-170.

Pitts, B.J.R. and L.R. Meyerson. 1981. Inhibition of $\mathrm{Na}$, K-ATPase activity and ouabain binding by sanguinarine. Drug Dev. Res. 1:43-49.

Powell, C.C. 1998. Products registered for disease management, p. 60-63. In: Tips on managing floriculture crop problems: Pests, diseases, and growth control. The Ohio Florists' Assn., Columbus, Ohio.

Presley, J.T. 1969. Growth response of Verticillium albo-atrum to sanguinarine in nutrient agar. Phytopathology 59:1968-1969.

Sakamoto, S. 1986. Studies of sanguinarine in collagenase expression and bone resorption models. Compend. Cont. Educ. Dent. Suppl. 7:221224

Schneegurt, M.A. and M.J. Henry. 1992. Effects of piperalin and fenpropidin on sterol biosynthesis in Ustilago maydis. Pest. Bioch. and Physiol. 43:45-52.

Ultrichova, J., D. Walterova, V. Preininger, and V. Simanek. 1983a. Inhibition of butyryl cholinesterase activity by some isoquinoline alkaloids. J. Med. Plant Res. 48:174-177.

Ultrichova, J., D. Walterova, V.Preininger, V. Slavik, J. Lenfeld, M. Cushman, and V. Simanek. 1983b. Inhibition of acetylcholinesterase by some isoquinoline alkaloids. Planta Med. 48:111-114.

Vallejos, R.H. 1973. Uncoupling of photosynthetic phosphorylation by benzophenanthridine alkaloids. Biochim. Biophy. Acta 292:193-196.

Vallejos, R.H. and O.A. Roveri. 1972. Alkaloid inhibition of yeast respiration: Prevention by $\mathrm{CA}^{2+}$. Biochem. Pharmacol. 21:3179-3182.

van den Brink, H.J.M., H.J.G.M. Nistelrooy, M.A. de Waard, C.A.M.J.J. van den Honel, and R.F.M. van Gorcom. 1996. Increased resistance to 14 alpha demethylase inhibitors (DMIs) in Aspergillus niger by coexpression of the Pencillium italicum eburicol 14 alpha demethylase (cyp51) and the A. niger cytochrome P540 reductase (cprA) genes. J. Biotech. 49:13-18.

Vichkanova, S.A. and V.V. Adgina. 1971. The antifungal properties of sanguinarine (in Russian). Antibiotiki 16:609-612.

Vichkanova, S.A., M.A. Rubinichik, and V.V. Adgina. 1969. Chemotherapeutic action of sanguinarine (in Russian). Farmakol Toksikol. 32:325-328.

Walternova, D., J. Ulrichova, V. Preininger, and V. Simanek. 1981. Inhibition of liver alanine aminotransferase activity by some benzophenanthridine alkaloids. J. Med. Chem. 24:1100-1103. 